\title{
Absence of human papillomavirus genomic sequences detected by the polymerase chain reaction in oesophageal and gastric carcinomas in Japan
}

\author{
Makoto Saegusa, Miki Hashimura, Yasuo Takano, Makoto Ohbu, Isao Okayasu
}

\begin{abstract}
Aims-To estimate the occurrence of human papillomavirus (HPV) infection in oesophageal or gastric carcinomas in patients in Japan.

Methods-103 oesophageal and 99 gastric carcinomas were investigated by polymerase chain reaction (PCR) assays using two consensus (targeting either the L1 or the E6-E7 regions) and two type specific (type 16 and 18) primer sets. A $\beta$ globin gene specific primer set was also applied to examine the quality of the extracted DNA. Results-Amplification of $\beta$ globin gene was clearly visible in $92(89.3 \%)$ of the 103 oesophageal, and $89(89.8 \%)$ of the 99 gastric carcinoma specimens. However, the entire series of tumour DNA was negative for HPV sequences by PCR assay using all four primer sets.

Conclusion-HPV is not likely to be involved in oesophageal or gastric tumorigenesis in Japanese patients.

(F Clin Pathol: Mol Pathol 1997;50:101-104)
\end{abstract}

Keywords: human papilloma virus; oesophageal carcinoma; gastric carcinoma

Human papillomaviruses (HPVs), members of the papovavirus family, are closed circular double stranded DNA viruses about 7.9 kilobases long that have been reported to demonstrate approximately 60 different genotypes. ${ }^{12}$ HPVs are subclassified into high risk (HPV-16, HPV-18, HPV-31), and low risk (HPV-6, HPV-11) categories on the basis of their association with malignant progression. ${ }^{3}$ The E6 protein of high risk HPV types has been shown to bind to the tumour suppressor p53 protein and the E7 protein binds to $\mathrm{Rb}$ protein, ${ }^{45}$ suggesting a possible role of HPV infection in tumour development. Earlier studies have demonstrated the presence of HPV genomes in several human cancers, particularly squamous cell tumours of the uterine cervix ${ }^{6}$ skin, ${ }^{7}$ conjunctiva, ${ }^{8}$ and upper respiratory tract. ${ }^{10}$

Oesophageal carcinomas have a distinct geographic distribution with a high prevalence in certain regions of Asia, Africa, Iran, France, and South America, ${ }^{11}$ and marked differences in incidence of about 300-fold between different areas or countries. ${ }^{2}$ Several risk factors have been suggested, such as cigarette smoking, excessive intake of alcohol and hot foods, and specific nutritional deficiencies. ${ }^{13}$ Some studies have demonstrated the presence of HPV DNA in oesophageal carcinoma samples using in situ hybridisation, polymerase chain $\overrightarrow{\vec{\omega}}$ reaction (PCR) and Southern blot techniques ${ }^{14}{ }^{15}$; other reports documented lack 3 of HPV sequences in tumour DNA investi- if gated by similar methods. ${ }^{16}{ }^{17}$ The question of $i$ whether HPV infection plays a role in the gen- $\vec{a}$ esis of oesophageal carcinomas in some populations, especially in high incidence areas, remains open.

The incidence of gastric carcinomas has also $\frac{T}{2}$ been found to demonstrate marked geographic variation. Although the majority of HPV related malignant tumours are squamous cell carcinomas, a few studies have demonstrated an association of HPVs with non-squamous cell carcinomas, such as adenocarcinomas of the uterine cervix ${ }^{18}$ and colon, ${ }^{19}$ and transitional cell carcinomas of the urinary bladder. ${ }^{20} \stackrel{\circ}{\circ}$

The present study investigated the occur- $\vec{\partial}$ rence of HPV infection in oesophageal and 3 gastric carcinomas arising from the upper digestive tract of Japanese patients by PCR assay using two consensus (L1 and E6-E7 regions) and two type specific (type 16 and 18) primer sets.

\section{Patients and methods}

CASES

One hundred and three oesophageal and 99 gastric carcinoma cases were selected from the patient charts of the authors' institution from N 1989 to 1994. All samples were surgically resected, and conventionally fixed in $10 \%$ formalin, and paraffin embedded. Histological classification was performed according to the criteria of the Japanese Society for Oesopha- 을 geal Disease $(1992)^{21}$ or the Japanese Research $\stackrel{\mathbb{D}}{\rightarrow}$ Society for Gastric Cancer (1993). ${ }^{22}$ Lesions were further classified into early and advanced 0

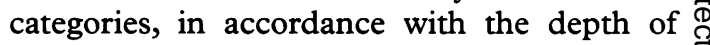
tumour invasion: to the mucosa and/or the $\stackrel{\mathbb{Q}}{\mathscr{Q}}$ submucosa in the former case, and into or through the muscularis propria in the latter.

\section{DNA EXTRACTION}

Several serial $10 \mu \mathrm{m}$ paraffin sections were $\frac{\overline{0}}{7}$ stained with $1 \%$ methyl green solution, tumour cells were then scraped off under the microscope, carefully avoiding contamination with areas of more than $25 \%$ to $30 \%$ normal cells. Tissue samples were treated with lysis buffer containing $100 \mu \mathrm{g} / \mathrm{ml}$ proteinase $\mathrm{K}$ (Merck, Darmstadt, Germany) at $48^{\circ} \mathrm{C}$ for 48 hours. 
Table 1 Primer sequences used for the polymerase chain reaction

\begin{tabular}{|c|c|c|c|c|c|}
\hline & Target region & & Primer sequence & Source & $\begin{array}{l}\text { Approximate } \\
\text { product size (base } \\
\text { pairs) }\end{array}$ \\
\hline \multirow[t]{2}{*}{ Consensus } & L1 & $\begin{array}{l}\text { L1C1 } \\
\text { L1C2 }\end{array}$ & $\begin{array}{l}\text { 5'-CGTAAACGTTTTCCCTATTTTTTT-3' } \\
\text { 5'-TACCCTAAATACTCTGTATTG-3' }\end{array}$ & Yoshikawa et a $P^{4}$ & 250 \\
\hline & E6-E7 & $\mathrm{pU}-1 \mathrm{M}$ & 5'-TGTCAAAAACCGTTGTGTCC-3' & Fujinaga $e t a l^{5}$ & $\begin{array}{l}240 \text { (Type } 16 \text { ) } \\
270 \text { (Type } 18 \text { ) }\end{array}$ \\
\hline \multirow[t]{2}{*}{ Type specific } & Type 16 (E6) & $\begin{array}{l}\text { pU-2R } \\
\text { p16-1 } \\
\text { p16-2R }\end{array}$ & $\begin{array}{l}\text { 5'-GAGCTGTCGCTTAATTGCTC-3' } \\
\text { 5'-MGGGCGTAACCGAAATCGGT-3' } \\
\text { 5'-GTTTGCAGCTCTGTGCATA-3' }\end{array}$ & Shimada et $a l^{6}$ & 140 \\
\hline & Type 18 (E6) & $\begin{array}{l}\text { p18-1 } \\
\text { p18-2R }\end{array}$ & $\begin{array}{l}\text { 5'-ACAGTATTGGMCTTACAGA-3' } \\
\text { 5'-GAATMAAATCTATACATTT-3' }\end{array}$ & Bloss $e t a l^{7}$ & 109 \\
\hline$\beta$ globin & & $\begin{array}{l}\text { BGLO3 } \\
\text { BGLO4 }\end{array}$ & $\begin{array}{l}\text { 5'-ATGGTGCACCTGACTCCTGAGG-3' } \\
\text { 5'-GCCATCACTAAAGGCACCGAGC-3' }\end{array}$ & Coates $e t a l^{3}$ & 355 \\
\hline
\end{tabular}

DNA extraction was performed by phenol/ chloroform treatment and precipitation overnight with ethanol. The DNA pellets were dissolved in distilled water and their concentrations determined by spectrophotometry. The quality of the DNA extracted was confirmed with a $\beta$ globin gene specific primer pair amplifying a 355 base pair fragment. ${ }^{23}$
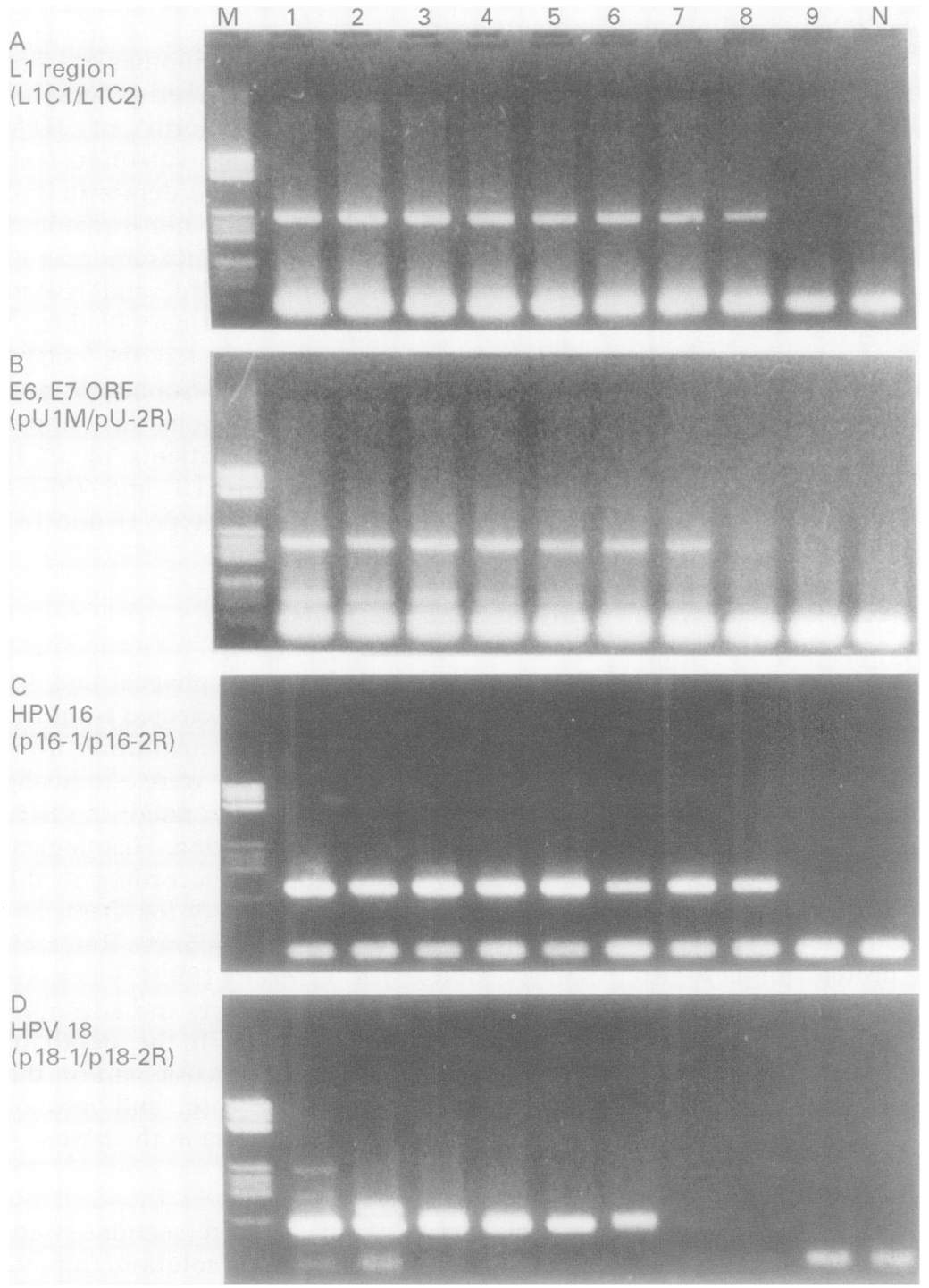

Figure 1 Sensitivity of PCR to amplify HPV DNA. Serial dilution series of subcloned $H P V$ type 16 and 18 DNA containing 50 ng normal human genomic DNA were amplified using primer pairs, L1C1/L1C2 (A), pU1M/pU-2R (B), p16-1/p16-2R (C), and p18-1/p18-2R (D). Concentrations of HPV DNA: lane 1, $1000 \mathrm{pg}$; lane 2, $100 \mathrm{pg}$; lane 3, 10 pg; lane 4, 1 pg; lane 5, 0.1 pg; lane 6, 0.01 pg; lane 7, 0.001 pg; lane 8, $0.0001 \mathrm{pg}$; lane 9, $0.00001 \mathrm{pg}$. M, molecular markers (DNA molecular markers $V$,

Boehringer Mannheim/Yamanouchi); N, negative control.
POLYMERASE CHAIN REACTION

Aliquots of DNA (50 ng) were used as templates in a reaction volume of $10 \mu \mathrm{l}$ containing $1 \mu \mathrm{M}$ each primer and $0.5 \mathrm{U}$ Taq DNA polymerase (Takara, Shiga, Japan) (table 1).

The consensus primers targeting the L1 region $(\mathrm{L} 1 \mathrm{C} 1 / \mathrm{L} 1 \mathrm{C} 2)^{24}$ are able to detect nine types of $\operatorname{HPV}(6,11,16,18,31,33,42,52$, and 58). The PCR analysis entailed 40 cycles of 30 seconds at $94^{\circ} \mathrm{C}$, two minutes at $48^{\circ} \mathrm{C}$, and two minutes at $72^{\circ} \mathrm{C}$. The other consensus primers targeting the $\mathrm{E} 6$ and $\mathrm{E} 7$ open reading frames (pU-1M/pU-2R) ${ }^{25}$ can amplify six types of HPV $(16,18,31,33,52 \mathrm{~b}$, and 58). The PCR analysis entailed 40 cycles of 30 seconds at $94^{\circ} \mathrm{C}$, two minutes at $55^{\circ} \mathrm{C}$, and two minutes at $72^{\circ} \mathrm{C}$. For determination of HPV subtypes, a restriction fragment length polymorphism assay was performed with digestion of the PCR products with appropriate restriction enzymes including Rsa-I, Dde-I, Hae-III, and Ava-II. The type specific primers (p16-1/p16-2R, ${ }^{26}$ and $\mathrm{p} 18-1 / \mathrm{p} 18-2 \mathrm{R}^{27}$ ) targeting the $\mathrm{E} 6$ open reading frame were able to amplify HPV-16 and HPV-18, respectively. The PCR reaction entailed 40 cycles of 30 seconds at $94^{\circ} \mathrm{C}$, two minutes at $55^{\circ} \mathrm{C}$, and two minutes at $72^{\circ} \mathrm{C}$.

To check for false positives, water instead of DNA was included with each amplification. As positive controls, cervical carcinoma cases confirmed to carry HPV types 16 and $18,{ }^{6}$ were used. PCR was carried out in duplicate or triplicate.

The sensitivity of the PCR assay using each primer set was examined with serial dilutions of subcloned HPV type 16 or 18 DNA containing $50 \mathrm{ng}$ normal genomic DNA of human liver tissues.

\section{Results}

Amplification of $\beta$ globin gene resulted in clearly visible products in $92(89.3 \%)$ of the 103 oesophageal carcinoma specimens, and 89 $(89.8 \%)$ of the 99 gastric carcinoma specimens, providing 181 carcinoma specimens for examination of HPV DNA detection.

At least $0.001 \mathrm{pg}$ of subcloned HPV DNA containing $50 \mathrm{ng}$ normal human genomic DNA could be detected by the PCR procedure using four primer sets (fig 1).

The 92 oesophageal tumours were histologically classified as $22(23.9 \%)$ well differentiated, $25(27.2 \%)$ moderately differentiated, 


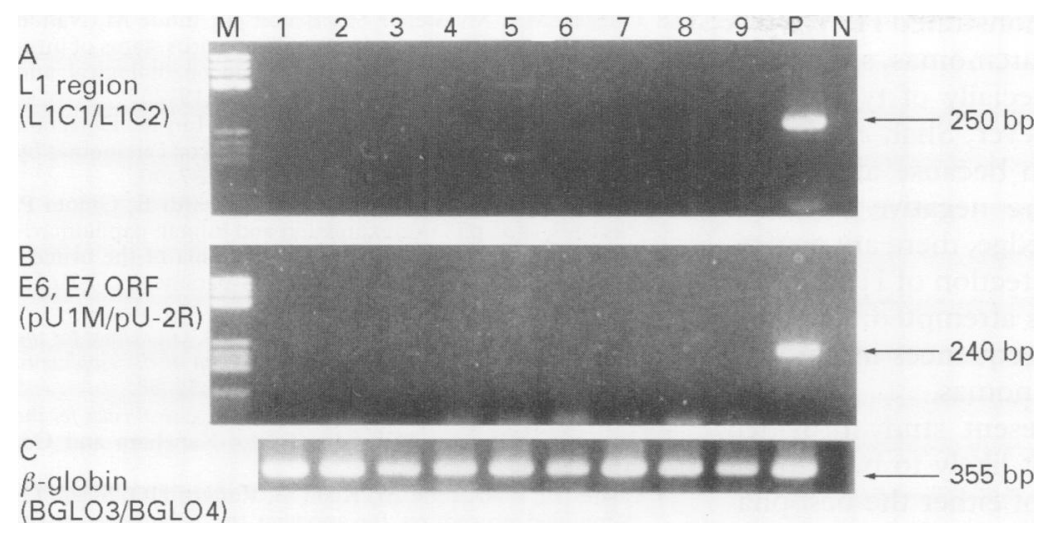

Figure 2 Results of PCR using two consensus primer sets, targeting regions $L 1(A)$ or E6-E7 open reading frames (ORF) (B). The positive control (P, HPV type 16 within cervical carcinoma case) is clearly amplified by both primers, while all tumour DNA (lanes 1-5, oesophageal carcinoma cases, lanes 6-9, gastric carcinoma cases) is negative. Appropriate molecular size products for the $\beta$ globin gene are consistently present in tumour and positive control samples (C). M, molecular markers (DNA molecular markers $V$, Boehringer Mannheim/Yamanouchi); $N$, negative control.
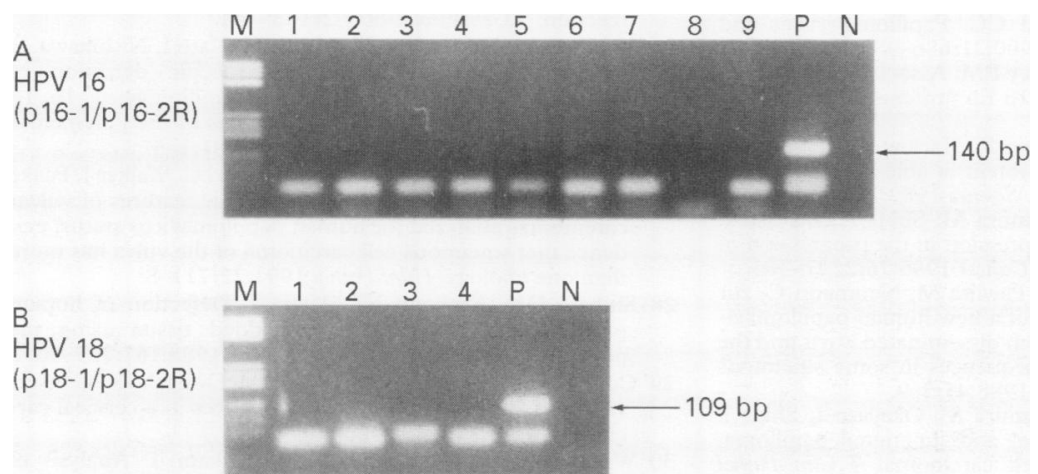

Figure 3 PCR using type specific primers. (A) PCR for HPV type 16. Lanes 1-5, oesophageal carcinoma cases, lanes 6-9, gastric carcinoma cases. P, positive control (HPV type 16 within a cervical carcinoma case), $N$, negative control. (B) PCR for HPV type 18 Lanes 1 and 2, oesophageal carcinoma cases; lanes 3 and 4, gastric carcinoma cases, $P$, positive control (HPV type 18 within a cervical carcinoma case); $N$, negative control. $M$, molecular markers (DNA molecular markers V, Boehringer Mannheim/Yamanouchi); , negative control.

and $45 \quad(48.9 \%)$ poorly differentiated squamous cell carcinomas, including 48 at early, and 44 at advanced stages. Eighty nine gastric lesions were classified as 21 (23.4\%) well differentiated, $23(25.8 \%)$ moderately differentiated, and $45(50.6 \%)$ poorly differentiated adenocarcinomas, 43 in early and 46 in advanced stages.

HPV genomic sequences could not be identified in any of the 92 oesophageal or 89 gastric tumour DNAs using consensus primers for either the HPV L1 region or the E6 and E7 open reading frames (fig 2). Type specific primers for HPV-16 and HPV-18 also failed to amplify the HPV DNA (fig 3). The positive controls always gave products showing the expected molecular size and negative controls were consistently negative (figs 2 and 3 ).

\section{Discussion}

Detection of HPV genomic sequences is strongly dependent on the sensitivity of the technique used: PCR can detect as few as 10 to 20 copies of HPV DNA ${ }^{28}$; in situ hybridisation (ISH) can detect 50 to 200 viral DNA copies. Although ISH allows the anatomical location of tumour cells demonstrating HPV infection to be distinguished, non-specific and false positive staining may occur. ${ }^{17}$ It has been reported that in PCR assays, detection of high risk HPV types by primers within the E6 gene region is more sensitive than the consensus primer sets, as the E6 and E7 genes, responsible for transforming ability, are highly conserved in most carcinomas, even when the virus is integrated into the host genome. ${ }^{29}{ }^{30}$ In the present study, we applied a comprehensive approach to detection using two consensus primers and two type specific primer sets. The PCR system with consensus primers for either the $\mathrm{L} 1$ region $(\mathrm{L} 1 \mathrm{C} 1 / \mathrm{L} 1 \mathrm{C} 2)$ or the $\mathrm{E} 6$ and $\mathrm{E} 7$ open reading frame (pU-1M/pU-2R) can detect 0.1 to 1.0 copy of the HPV genome per $\overparen{\nabla}$ cell, ${ }^{24}{ }^{25}$ and the type specific primers (p16-1/ p16-2R) can amplify $10^{-5}$ to $10^{-6}$ viral copies per cell by combination of PCR and dot blot hybridisation $^{24}$; these values are supported by $\overrightarrow{\vec{\omega}}$ our results for the sensitivity of HPV DNA detection on PCR assay using same primer sets. Thus, our detection assay was of relatively or high sensitivity; however, it is possible that some HPV positive specimens with extremely low levels of HPV DNA could have been missed.

A possible role for HPV in oesophageal carcinogenesis was initially suggested by the finding of morphological koilocytotic changes of oesophageal mucosa in patients with oesophageal squamous cell carcinomas. ${ }^{31}$ Recent molecular biological analyses demonstrated that positive rates for the presence of HPV genomes in oesophageal carcinomas vary from $0 \%$ to $71 \%,{ }^{17} 32$ with marked differences depending on the geographic location of the patient population. Suzuk et $a l^{33}$ have suggested that the role of HPV may be more pronounced in areas of 3 the world with a high incidence of the disease, and may be less important in areas with moderate or low risk for oesophageal carcinomas. Benamouzig et $a l^{17}$ failed to detect any HPV DNA sequences in patients from two areas of France with oesophageal carcinomas, one area $\delta$ with the highest incidence $(28.6$ per 100000 population) and the other with an intermediate incidence (12 per 100 000), by PCR using consensus and type specific primer sets.

Recently, the incidence of oesophageal carcinoma in Japan has gradually increased with an estimated 11.1 per 100000 population intermediate value. ${ }^{34}$ Previous studies of Japanese $\omega$ patients with oesophageal carcinomas demonstrated rates of HPV DNA detection from $0 \%$ to $33.8 \%$ ( 0 of 34 cases (PCR and Southern $\stackrel{D}{\oplus}$ blot methods), ${ }^{35} 3$ of 45 (PCR), ${ }^{36} 2$ of 15 (immunohistochemistry), ${ }^{37} 1$ of 4 (PCR and Southern blot), ${ }^{15}$ and 24 of 71 cases (ISH) ${ }^{38}$ ). In the present study, HPV DNA sequences could not be detected in any oesophageal tumour DNA, globin sequences were generally amplified, and positive controls were always positive. Although one reason for the variation in frequency could be differences in the sensitivity and specificity of the techniques applied, we conclude from the present data that HPV is not of aetiological significance for the majority of oesophageal carcinomas in Japanese patients.

The presence of HPV in adenocarcinomas has been documented in a few reports. ${ }^{18}$ 
Cheng $e t a l^{19}$ recently demonstrated HPV DNA sequences in colorectal carcinomas, suggesting a possible viral role, especially of type 16 , in large bowel cancer. However, Shah et al ${ }^{39}$ cast doubt on this association because all tumour DNA in their study were negative for HPV sequences. To our knowledge, there are no previous studies in which detection of HPV DNA in gastric carcinomas was attempted; we failed to detect HPV genomic sequences in any of a large series of adenocarcinomas.

In conclusion, the present study provided evidence that HPV is not likely to be a major factor in carcinogenesis of either the oesophagus or the stomach in the Japanese population.

1 Snijders PJF, van den Brule AJC, Schrijnemakers HFI Snow G, Meifer CJLM, Walboomers JMM. The use of gereral primers in the polymerase chain reaction permits the detection of a broad spectrum of human papillomavirus genotypes. F Gen Virol 1990;71:173-81.

2 zur Hausen H. Viruses in human cancers. Science 1991;254 $1167-73$

3 Arends MJ, Wyllie AH, Bird CC. Papillomaviruses and human cancer. Hum Pathol 1990;21:686-98.

4 Werness BA, Levine AJ, Howley PM. Association of human papillomavirus types 16 and $18 \mathrm{E} 6$ proteins with p53. $S_{\mathrm{ci}}$ ence 1990;248:76-9.

5 Dyson N, Howley PM, Munger K, Harlow E. The human papillomavirus-16 E7 oncoprotein is able to bind to the retinoblastoma gene product. Science 1989;243:934-7.

6 Saegusa M, Takano Y, Hashimura M, Shoji Y, Okayasu I. The possible role of bcl-2 expression in the progression of tumors of the uterine cervix. Cancer 1995;76:2297-303.

7 Grimmel M, de Villiers EM, Pawlita M, Neumann C, zu Hausen $H$. Characterization of a new human papillomavirus type (HPV41) isolated from disseminated warts and the detection of closely related sequences in some squamous cell carcinomas. Int $\mathcal{f}$ Cancer $1988 ; 45: 5-9$.

8 Saegusa M, Takano Y, Hashimura M, Okayasu I, Shiga J. HPV type 16 in conjunctival and junctional papilloma dysplasia, and squamous cell carcinoma. $\mathcal{f}$ Clin Pathol dysplasia, and squar

9 Scheurlen W, Stremlau A, Gissmann L, Hohn D, Zenner $\mathrm{HP}$, zur Hausen H. Rearranged HPV 16 molecules in an anal carcinoma and in a laryngeal carcinoma. Int $\mathcal{f}$ Cance 1986;38:671-6.

10 Syrjanen K, Syrjanen S, Kellokoski J, Mantyjarvi R. Human papillomavirus (HPV) type 6 and 16 DNA sequences in bronchial squamous cell carcinomas demonstrated by in situ DNA hybridization. Lung 1989;167:33-42.

11 Whelan SL, Parkin DM, Masuver E. Patterns of cancer in five continents. IARC Scientific Publications No, 102 fyon: International Agency for Research on Cancer, 1990: Lyon: In

12 Day NE. The geographic pathology of cancer of the oesophagus. Br Med Bull 1984;40:329-34.

13 Warwick GP, Harington JS. Some aspects of the epidemiol ogy and etiology of esophageal cancer with particular emphasis on the Transkei, South Africa. Adv Cancer Res 1973;17:81-229.

14 Fidalgo PO, Cravo ML, Chaves PP, Leitao CN, Mira FC. High prevalence of human papillomavirus in squamous cell carcinoma and matched normal esophageal mucosa: carcinoma and matched normal esophageal mucosa: assessm

15 Togawa K, Jaskiewicz K, Takahashi H, Meltzer SJ, Rustg AK. Human papillomavirus DNA sequences in esophagu squamous cell carcinoma. Gastroenterology 1994;107:128 36.

16 Loke SL, Ma L, Wong M, Srivastava G, Lo I, Bird CC. Human papillomavirus in oesophageal squamous cell carcinoma. F Clin Pathol 1990;43:909-12.

17 Benamouzig R, Jullian E, Chang F, Robaskiewicz M, Flejou $\mathrm{J}-\mathrm{F}$, Raoul J-L, et al. Absence of human papillomavirus DNA detected by polymerase chain reaction in French patients with esophageal carcinoma. Gastroenterology 1995; 109: $1876-81$.
18 Duggan MA, McGregor SE, Benoit JL, Inoue M, Nation JG, Stuart GCE. The human papillomavirus status of invasive cervical adenocarcinoma: a clinicopathological and outcome analysis. Hum Pathol 1995;26:319-25.

19 Cheng JY, Sheu LF, Meng CL, Lee WH, Lin JC. Detection of human papillomavirus DNA in colorectal carcinomas by polymerase chain reaction. Gut 1995;37:87-90.

20 Tenti P, Zappatore R, Romagnoli S, Civardi E, Giunta P, Scelsi R, et al. p53 overexpression and human papillomavirus infection in transitional cell carcinoma of the urinary bladder: correlation with histological parameters. 7 Pathol 1996;178:65-70

21 Japanese Society for Esophageal Diseases. Guidelines for the clinical and pathologic studies on carcinoma of the esophagus. 8th edn. Tokyo: Kanehara and Co, 1992:32-58.

22 Japanese Society for Gastric Cancer. The general rules for the gastric cancer study: 12th edn. Tokyo: Kanehara and Co, 1993:60-89.

23 Coates PJ, d'Ardenne AJ, Khan G, Kangro HO, Slavin G Simplified procedures for applying the polymerase chain reaction to routinely fixed paraffin wax sections. $f$ Clin Pathol 1991;44:115-8.

24 Yoshikawa H, Kawana T, Kitagawa K, Mizuno M, Yoshikura H, Iwamoto A. Detection and typing of multiple genital human papillomaviruses by DNA amplification with consensus primers. Fpn f Cancer Res 1991;82:524-31.

25 Fujinaga Y, Shimada M, Okazawa K, Fukushima M, Kato I, Fujinaga K. Simultaneous detection and typing of genital human papillomavirus DNA using the polymerase chain reaction. F Gin Virol 1991;72:1039-44.

26 Shimada M, Fukushima M, Mukai H, Kato I, Nishikawa A, Fujinaga $\mathrm{K}$. Amplification and specific detection of transforming gene region of human papillomavirus 16,18 and 33 in cervical carcinoma by means of the polymerase chain reaction. Ipn $\mathcal{f}$ Cancer Res 1990;81:1-5.

27 Bloss JD, Liao S-Y, Wilczynski SP, Macri C, Walker J, Peake $\mathrm{M}$, Berman ML. Clinical and histologic features of vulvar carcinomas analyzed for human papillomavirus status: evidence that squamous cell carcinoma of the vulva has more than one etiology. Hum Pathol 1991;22:711-8.

28 Shibata DK, Arnheim N, Martin J. Detection of human papillomavirus in paraffin embedded tissue using the polymerase chain reaction. $f$ Exp Med 1988;167:225-30

29 Cone RW, Minson AC, Smith MR, McDougall JK. Conservation of HPV-16 E6/E7 ORF sequences in a cervical carcinoma. f Med Virol 1992;37:99-107.

30) Wagatsuma $M$, Hashimoto $K$, Matsukara $T$. Analysis of integrated human papillomavirus type 16 DNA in cervical cancers: amplification of viral sequences together with cellular flanking sequences. F Virol 1990;64:813-21.

31 Syrjanen KJ. Histological changes identical to those of condylomatous lesions found in esophageal squamous cell carcinomas. Archic fur Geschwulstforsch 1982;52:284-92.

32 Williamson AL, Jaskiewicz K, Gunning A. The detection of human papillomavirus in oesophageal lesions. Anticancer Res 1991;11:263-6

33 Suzuk L, Noffisinger AE, Hui YZ, Fenoglio-Preiser CM. Detection of human papillomavirus in esophageal squamous cell carcinoma. Cancer 1996;78:704-10.

34 Health and Welfare Statistics Association. Fournal of Health and Welfare Statistics. 1996;43:430.

35 Akutsu N, Shirasawa H, Nakano K, Tanzawa H, Asano T, Kabayashi S, et al. Rare association of human papillomavirus DNA with esophageal cancer in Japan. $\mathcal{F}$ Infect Dis 1995;171:425-8.

36 Toh Y, Kuwano H, Tanaka S, Baba K, Matsuda H, Sugimachi K, et al. Detection of human papillomavirus DNA in esophageal carcinoma in Japan by polymerase chain reaction. Cancer 1992;70:2234-8.

37 Mori $M$, Shimono $R$, Inoue $T$, Kuwano $H$, Sugimachi K. Papillomavirus and esophageal cancer in the Japanese and Chinese. Am ₹ Gastroenterol 1989;84:1126-7.

38 Furihata M, Ohtsuki Y, Ogashi S, Takahashi A, Tamiya T, Ogata T. Prognostic significance of human papillomavirus genomes (type-16,-18) and aberrant expression of p53 protein in human esophageal cancer. Int $\mathcal{F}$ Cancer 1993;54: $226-30$

39 Shah KV, Daniel RW, Simons JW, Vogelstein B. Investigation of colon cancers for human papillomavirus genomic sequences by polymerase chain reaction. I Surg Oncol 1992;51:5-7. 